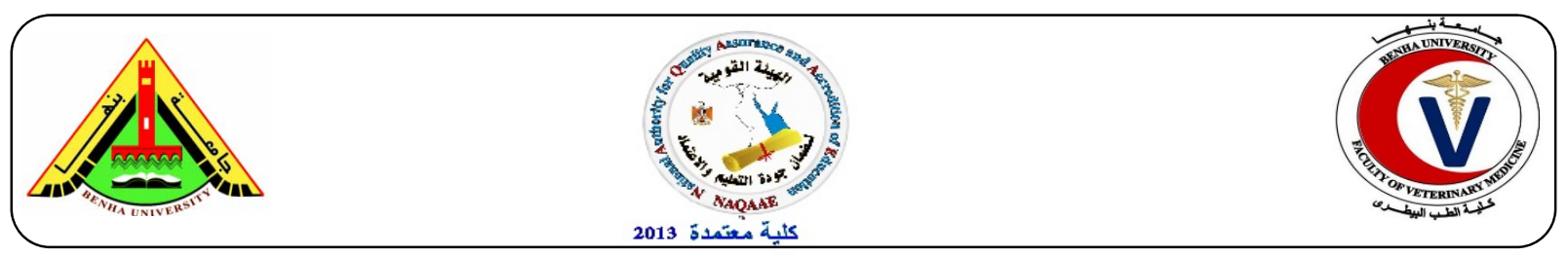

\title{
Prevalence and molecular characterization of Pseudomonas species in frozen imported meat
}

\author{
${ }^{\text {a }}$ Hemmat M. Ibrahim, a'Hassan, M. A, bahla A bou El-Roos, Mohga Abd Elsalam, A. \\ ${ }^{a}$ Food Control Dept., Fac. Vet. Med., Benha University. ${ }^{b}$ Animal Health Research Institute, Shbin Elkoom
}

\section{A B S T R A C T}

A total of 90 random samples of Frozen American, Brazilian and Indian meat samples (30 of each) were collected from different retail shops and supermarkets in EL-Menofeya Governorate at different production dates. The collected samples were examined bacteriologically and by using PCR tecnique for detection of Pseudomonas species, especially Ps.aeruginosa. There for , Ps. aeruginosa , Ps.alcaligenes, Ps.cepacia , Ps. fluorescence , Ps. proteolytica , Ps. Psychrophila, Ps. putrifaciens, Ps.thermotolerans, Ps. versicularis , Ps. fragi,Ps.Putida Ps.orientalis and Ps.stutzeri were isolated from 2(6.67\%), 5 (16.67\%), 1 (3.33\%), 14 (46.67\%), 8 (26.67\%), 3(10\%), $10(33.33 \%), 6(20 \%), 1(3.33 \%)$ and zero for Ps.fragi,Ps.Putida,Ps.orientalis and Ps.stutzeri for frozen American meat samples ,3 (10\%), $8(26.67 \%), 1$ $(3.33 \%), 19(63.33 \%), 5(16.67 \%), 7(23.33 \%), 13(43.33 \%), 9(30 \%) 3(10 \%), 2(6.67 \%), 1(6.67 \%)$ and zero for Ps.orientalis one Ps.stutzeri , for frozen Brazilian meat samples, 6(20\%),9(30\%),4 (13.33\%),25(83.33\%),6 (20\%), 11(36.67),19(63.33\%), 13(43.33\%), 4(13.33\%), 3(10\%), 3(10\%), 1(3.33\%) and 2(6.67\%) for frozen Indian meat samples, respectively. Regarding to Ps.aeruginosa the total number and percentage of ps.aeruginosa were $2(6.67 \%)$, $3(10 \%)$ and 6(20\%) for American , Brazilian and Indian frozen meat, respectively with total result of $(12.22 \%)$. By using PCR technique, the all examined samples by conventional method showed positive result by both of PCR and conventional method to Pseudomonas species. On the other hand of Ps. aeruginosa was detected in one sample of Indian meat by conventional method while it showed negative result by PCR technique.

Key words: Pseudomonas, frozen meat, molecular characterization, PCR, PA- GS, PA-SS.

(http://www.bvmj.bu.edu.eg)

(BVMJ-31(2): 220-224, 2016)

\section{INTRODUCTION}

The increase in beef imports is a attributed to the increase in demand for frozen beef resulting from Egypt's new policy to provide frozen beef at reduced affordable prices to food subsidy beneficiaries. The expected increase in demand will increase total meat consumption with current low meat production, beef imports will be the main option to bridge the gap between the consumption and domestic supply. The main flora responsible for spoilage of fresh and refrigerated meat during aerobic storage belongs to genus pseudomonas (Widders et al., 1995). The factors which make the psychrotrophic microorganisms important in food are their ubiquitous distribution in the atmosphere in which the meat is handled and stored (Mousa et al., 1998). The ability of psychrotrophic bacteria such as pseudomonas to use simple nitrogenous foods, their proteolytic and lipolytic activity of some species, their aerobic tendency enabling them to grow rapidly and produce oxidized products and slime at the surface of food, where heavy contamination is most likely, their ability to grow at low temperature, and pigment production by some species (Frazier and Westhoff, 1984). The pseudomonas genus induces more than 140 species and represents the most psychrotrophic bacteria which are highly Proteolytic and / or strong lipolytic leading to biological changes in the composition of meat and meat products particularly at low temperature (Gill and Newton, 1982).

So, the current study prevalence of pseudomonas in frozen imported meat with special reference to ps. aeruginosa, as it has public health hazard and affect meat keeping quality.

\section{MATERIAL AND METHODS}

\subsection{Collection of samples}

A grand total of ninety random samples of three types of imported frozen boneless raw meat from random cuts (Brazilian, Indian, American and (30 of each) were collected from different shops and 
super markets at El - Menoufia province. The collected samples were kept in separate plastic bags and transferred directly to the laboratory in an insulated ice box under complete aseptic conditions without undue delay to evaluate their bacteriological quality

\subsection{Preparation of samples (International Commission on Microbiological Specification for Food" (International Commission On Microbilogical Specification for Food" ICMSF", 1996)}

To 25 grams of the examined sample, $225 \mathrm{ml}$ of sterile peptone water $(0.1 \%)$ were aseptically added and thoroughly homogenized (1/10 dilution). One $\mathrm{ml}$ from the original dilution was transferred to another sterile tube containing $9 \mathrm{ml}$ of sterile buffered peptone water and mixed well to make the next dilution, from which further decimal serial dilution were prepared. The prepared dilutions were subjected to the following examinations.

\subsection{Isolation and identification of Pseudomonas species (Kreig and Holt, 1984)}

Pseudomonas agar medium was recommended for the selective isolation of ps.spp.0.1 ML of the homogenates was evenly spread over a dry plate and using sterile bent glass speeder. After thorough mixing, the inoculated and control plates were incubated at $25^{\circ} \mathrm{C}$ for 48 hours. Pseudomonas species showed bluish green colonies. The suspected colonies of Pseudomonas species were then picked up and inoculated into semisolid nutrient agar tubes for further biochemical identifications. Identification of Pseudomonas species: The isolated Bactria were further identified acc. To the quid lines recommended by Macfaddin (2000) by morphological and biochemical test.

\subsection{Application of PCR}

\subsubsection{Primer sequences of Pseudomonas arugionosa used for PCR (table 3).}

\subsubsection{DNA Extraction using QIA amp kit (Shah et al., 2009).}

Bacterial DNA was extracted from the isolated Pseudomonas species to be ready for PCR. Briefly, a single colony was suspended in $20 \mathrm{ul}$ of lysis buffer containing $0.25 \%(\mathrm{w} / \mathrm{v})$ sodium dodecyl sulfate and $0.05 \mathrm{~mol} \mathrm{NaOH}$. After incubation for 15 min at $95^{\circ} \mathrm{C}, 180 \mathrm{ul}$ of sterile $\mathrm{dH} 2 \mathrm{O}$ was added. Extracts were centrifuged for $5 \mathrm{~min}$ at $13000 \mathrm{~g}$ to remove debris. The lysis suspension was stored at $-20^{\circ} \mathrm{C}$ till use.

\subsubsection{DNA Amplification (Papagiannoulis et al., 2010)}

The amplification was performed on a Thermal Cycler (Master cycler, Eppendorf, Hamburg, Germany). The PCR amplification was performed in a final volume of $25 \mu \mathrm{l}$ containing $2 \mathrm{mmol}$ $\mathrm{MgCl} 2,1$ x PCR buffer, 250 umol (each) deoxynucleoside triphosphates, 0.4 umol primer, $1 \mathrm{U}$ Taq polymerase and $2 \mu 1$ of whole- cell bacterial lysate and adjusted to $25 \mu \mathrm{l}$ by the addition of sterile $\mathrm{d} \mathrm{H}_{2} \mathrm{O}$. After an initial step of 2 min at $95^{\circ} \mathrm{C}, 25$ cycles were completed each consisting of 20 secs at $94^{\circ} \mathrm{C}, 20$ secs at $54^{\circ} \mathrm{C}$, 40 secs at $72^{\circ} \mathrm{C}$ and a final extension step of 1 $\min$ at $72^{\circ} \mathrm{C}$. Amplified products were analyzed by $2 \%$ of agarose gel electrophoresis (Applichem, Germany, GmbH) in 1x TBE buffer stained with ethidium bromide and captured as well as visualized on UV transilluminator. A $100 \mathrm{bp}$ plus DNA Ladder (Qiagen, Germany, GmbH) was used to determine the fragment sizes.

\section{RESULTS}

As shown from data in table (1) the total number and percentage of pseudomonas species isolated from examined frozen imported meat were 22(73.33\%), 23 (76.67\%) and 28 (93.33\%) from frozen American, Brazilian and Indian meat, respectively with total result of $73(81.11 \%)$. In general, Ps orientalis and Ps. stutzeri were not isolated from frozen American and Brazilian meat and Ps. fragi and Ps. putida were not found in American meat.

The incidence of identified Ps. species. isolated from the examined samples of frozen meat (Table 2) appeared that Ps. aeruginosa, Ps. alcaligenes, Ps. cepacia, Ps. fluorescence, Ps. proteolytica, Ps. Psychrophila, Ps. putrifaciens, Ps. thermotolerans, Ps. versicularis, Ps. fragi, Ps. Putida Ps. orientalis and Ps. stutzeri were isolated from 2(6.67\%), 5 ( $16.67 \%), 1$ ( $3.33 \%), 14$ ( $46.67 \%), 8$ ( $26.67 \%)$, $3(10 \%), 10(33.33 \%), 6(20 \%), 1(3.33 \%)$ and zero for Ps. fragi, Ps. Putida, Ps. orientalis and Ps. stutzeri for frozen American meat samples, respectively $3(10 \%), 8(26.67 \%), 1(3.33 \%), 19$ (63.33\%), 5 (16.67\%), 7 (23.33\%), 13(43.33\%), 9 ( $30 \%) 3(10 \%), 2(6.67 \%), 1(6.67 \%)$ and zero for Ps. orientalis one Ps. stutzeri , for frozen Brazilian meat samples , 6(20\%), 9(30\%), 4 ( $13.33 \%)$, $25(83.33 \%), 6(20 \%), 11(36.67), 19(63.33 \%)$, $13(43.33 \%), \quad 4(13.33 \%), \quad 3(10 \%), \quad 3(10 \%)$, $1(3.33 \%)$ and $2(6.67 \%)$ for frozen Indian meat.

However, the m-PCR not only may replace the more labor-intensive conventional culturing 
techniques, but also allows the detection of species that are present at low levels (three or four orders of magnitude lower than the dominant species) that can remain undetected by plating. At a certain level, the m-PCR might be considered a quantitative (or better yet, a semi-quantitative) technique, since, once it has been established, the detection limit can be retrieved and used as the minimal microbial concentration detectable (Settanni and Corsetti.,2007).

Comparing with conventional and PCR technique the incidence of Ps. aeruginosa were the similar but there is increase in one sample by conventional method than PCR for Indian meat table (4) Fig (2).

Using PCR technique, the all examined samples by conventional method show positive result by both of PCR and conventional method to Ps. species on other hand the examined sample for detection of Ps. oeruginosa were one sample were positive by conventional method while it shows negative result by PCR technique (in Indian meat samples, fig (1).

Table (1): Incidence of Pseudomonas species in the examined samples of frozen imported meat $(n=30)$.

\begin{tabular}{ccc}
\hline Country origin & No. & $\%$ \\
\hline American meat & 22 & 73.33 \\
Brazilian meat & 23 & 76.67 \\
Indian meat & 28 & 93.33 \\
Total (90) & 73 & 81.11 \\
\hline
\end{tabular}

$\%$ was calculated according to total number of samples

Table (2): Incidence of identified pseudomonas species isolated from the examined samples of frozen meat ( $\mathrm{n}=30$ ) of each.

\begin{tabular}{lcccccc}
\hline \multicolumn{1}{c}{ Type of meat } & \multicolumn{2}{c}{ American } & \multicolumn{2}{c}{ Brazilian } & \multicolumn{2}{c}{ Indian } \\
Pseudomonas species & No & $\%$ & No & $\%$ & No & $\%$ \\
\hline Ps. aeruginosa & 2 & 6.67 & 3 & 10 & 6 & 20 \\
Ps. alcaligenes & 5 & 16.67 & 8 & 26.67 & 9 & 30 \\
Ps. Cepacia & 1 & 3.33 & 1 & 3.33 & 4 & 13.33 \\
Ps. Fluorescence & 14 & 46.67 & 19 & 63.33 & 25 & 83.33 \\
Ps. proteolytica & 8 & 26.67 & 5 & 16.67 & 6 & 20 \\
Ps. Psychrophila & 3 & 10 & 7 & 23.33 & 11 & 36.67 \\
Ps. Putrifaciens & 10 & 33.33 & 13 & 43.33 & 19 & 63.33 \\
Ps. Thermotolerans & 6 & 20 & 9 & 30 & 13 & 43.33 \\
Ps. Vesicular is & 1 & 3.33 & 3 & 10 & 4 & 13.33 \\
Ps. Fragi & - & - & 2 & 6.67 & 3 & 10 \\
Ps. Putida & - & - & 1 & 6.67 & 3 & 10 \\
Ps. orientalis & - & - & - & - & 1 & 3.33 \\
Ps. stutzeri & - & - & - & - & 2 & 6.67 \\
\hline
\end{tabular}

The percentage were calculated according to number of samples

Table (3): Primer sequences of pseudomonas species used for PCR: Application of single plex PCR for molecular characterization of 16S rRNA either for genus-specific (Psedomonas species) or species -specific ( $P$.s aeruginosa) was adopted using the following primers:

\begin{tabular}{ccccc}
\hline Target & Primers & Oligonucleotide sequence $(5 ' \rightarrow 3$ ') & Product size $(\mathrm{bp})$ & References \\
\hline Pseudomonas & PA-GS $(\mathrm{F})$ & 5' GACGGGTGAGTAATGCCTA '3 & & Spilker et al. \\
species & PA-GS (R) & 5' CACTGGTGTTCCTTCCTATA '3 & 618 & $(2004)$ \\
& PA-SS (F) & 5' GGGGGATCTTCGGACCTCA '3 & & \\
P. aeruginosa & PA-SS $(\mathrm{R})$ & 5' TCCTTAGAGTGCCCACCCG '3 & 956 & \\
\hline
\end{tabular}


Table (4): Percentage of Ps. aeruginosa identified by conventional and PCR techniques in the examined samples of frozen imported meat $(n=30)$.

\begin{tabular}{ccccc}
\hline \multirow{2}{*}{ Country origin } & & & & \\
& No. & $\%$ & No. & $\%$ \\
\hline American meat & 2 & 6.67 & 2 & 6.67 \\
Brazilian meat & 3 & 10 & 3 & 10 \\
Indian meat & 6 & 20 & 5 & 16.67 \\
Total (90) & 11 & 12.22 & 10 & 11.11 \\
\hline
\end{tabular}

$\%$ was calculated according to total number of samples

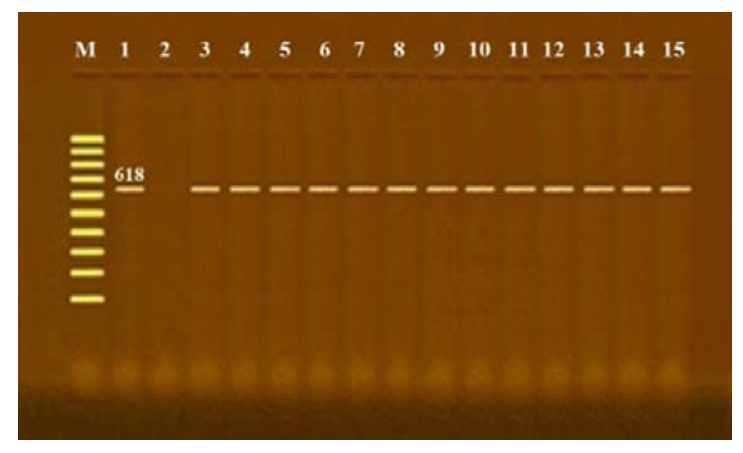

Photograph (1): Agarose gel electrophoresis of PCR amplification products using PA-GS primer (618 bp) as specific primer for identification of Pseudomonas species. Lane M: $100 \mathrm{bp}$ ladder as molecular DNA marker. Lane 1: Control positive for 16S rRNA of Pseudomonas species. Lane 2: Control negative. Lanes from 3 to 15: Positive Pseudomonas species.

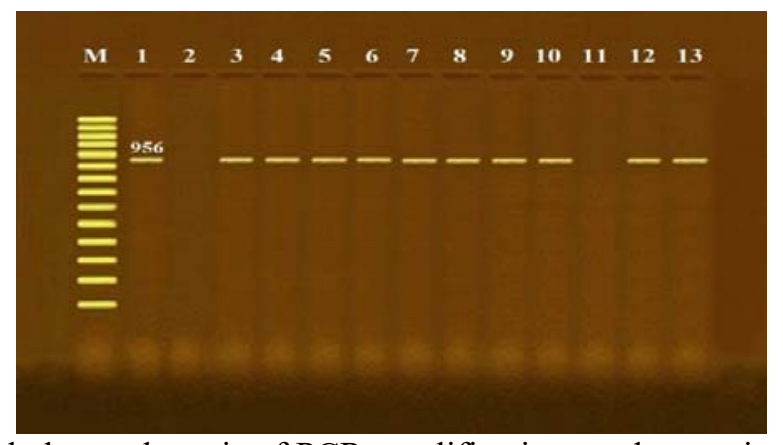

Photograph (2): Agarose gel electrophoresis of PCR amplification products using PA-SS primer (956 bp) as specific primer for identification of Pseudomonas aeruginosa. Lane M: $100 \mathrm{bp}$ ladder as molecular DNA marker. Lane 1: Control positive Pseudomonas aeruginosa. Lane 2: Control negative. Lanes 3, 4, 5, 6, 7, 8, 9, 10, 12 and 13: Positive Pseudomonas aeruginosa. Lane 11: Negative Pseudomonas aeruginosa.

\section{DISCUSSION}

Healthy animals and hygienically slaughtered animals after resting and fasting provide a practically aseptic meat (FAO, 1991). The imported frozen meat was often more heavily contaminated than home slaughtered meat. The problems that arise during transportation and retail distribution were usually similar to those of storage but additional factors play a part such as poor ventilation, rise in temperature, moist and unclean surface, those enhanced the microbial growth and increased the chance of meat contamination (Hayes, 1992).

From the previous results, Ps. fluorescence and Ps. alcaligenes represented major species, which could be isolated, this may reflect its resistance against many stress factors such as low temperature, water activity and inhibitory action of 
carbon dioxide. These finding agree with Rizk (2014); Sallam (1993).

The presence of Ps.species.in food creates a great risk as they lead to food poisoning and spoilage of food (Jay, 2000). On contrast the incidence of Ps. aeruginosa reflect minor resistance against stress factor as low temp. and water activity. These finding agree with those recorded by British Frozen Food Federation (BFFF) (2009); Todar (2004); Wallace (2003).

\section{REFERENCES}

British Frozen Food Federation (BFFF), 2009. Improving the Energy Efficiency of the cold chain, London

FAO, 1991. Manual on meat cold store operation and management. FAO Animal Production And Health Paper 92, Rome, Italy.

Frazier, W.C., Westhoff, D.C., 1984. Contamination, preservation and spoilage meat in meat microbiology, 4th ed. Graw Hill, New york.

Gill, C.O., Newton, K.G., 1982. The effect of Lactic acid concentration on the growth of meat gram negative psychrotrophs from a meat workers. Appl. Environ. Microbiol. 43, 284-288.

Hayes, P.R., 1992. Food Microbiology and Hygiene, London and New York.

International Commission On Microbilogical Specification for Food" ICMSF", 1996. Microorganismsn foods, characteristic of food microbial pathogens, Listeria moncytogene c. Blackie Academic Professional, London.
Jay, J.M., 2000. Taxonomy role and significance of $\mathrm{m}$.o in food .In modern food microbiology. Aspen publishers, Gaithersburg MD.P.B.

Kreig, N.R., Holt, J.N., 1984. Bergey's manual of systemic Bacteriology. williams and wilkins, Baltimore,M.D.21202, USA.

Macfaddin, J.F., 2000. Biochemical tests of identification of medical bacteria, 3rd ed. Lippincott Williams and Wilkins, Washington, Philadelphia . USA. .

Mousa, M.M.I., Edris, A.M., yassien, N.A., 1998. Microbiological monitoring of meat and cold Stored. Alex. J. vet. sci. 4, 203-211.

Papagiannoulis, A., Mathiopoulos, K., Mossialos, D., 2010. Molecular detection of the entomopathogenic bacterium Pseudomonas entomophila using PCR. Letters in Appl. Microbiol. 50, 241-245

Rizk, H. 2014. Microbiological evaluation in some frozen imported meat. M.V.SC, Banha university, Egypt.

Sallam, K.H.I. 1993. Psychrotrophic bacteria In meat and some meat Products. M.V.SC Thesis, Zagazig University, Egypt.

Shah, D., Shringi, S., Besser, T., Call, D., 2009. Molecular detection of foodborne pathogens, Boca Raton. . CRC Press, In Liu, D. Taylor \& Francis group, Florida, USA.

Todar, S., 2004. on line text book of bacteriology. Text book of bacteriology.

Wallace, O., 2003. How long Frozen meat stay fresh? www.wisegeek.org. .

Widders, P.R., Coates, K.J., Warner, S., Beattie, J.C., Morgan, I.R., Hickey, M.W., 1995. Controlling microbial contamination on beef and lamb meat during processing. Aust. Vet. J. 72, 208-211. 